\title{
Regulation of fos-lacZ fusion gene expression in primary mouse epidermal keratinocytes isolated from transgenic mice
}

\author{
Wendy B. BOLLAG, ${ }^{*}$ Yimin XIONG, Janet DUCOTE and Charles S. HARMON† \\ Preclinical Dermatology Research, Hoffmann-La Roche Inc., 340 Kingsland Street, Nutley, NJ 07110, U.S.A.
}

The expression of a fos-lac $Z$ fusion gene was studied in primary mouse epidermal keratinocytes obtained from transgenic mice. This gene construct contains the entire upstream regulatory sequence of c-fos, and expression of the endogenous and fusion gene was shown by Northern analysis to correlate upon induction with the phorbol ester 12-O-tetradecanoylphorbol 13-acetate (TPA). Using a chromogenic substrate of $\beta$-galactosidase, we also demonstrated that expression of the fusion gene product, like that of Fos, was localized to the cell nucleus. In addition, we showed that epidermal keratinocytes responded to dialysed fetal bovine serum (FBS), TPA and high-calcium medium with enhanced Fos-lacZ expression and an inhibition of proliferation. The time course of induction of Fos-lacZ expression was similar for dialysed FBS and TPA, with a peak $\sim 2 \mathrm{~h}$ after exposure.
Exposure for $\sim 24 \mathrm{~h}$ to an elevated extracellular calcium concentration was required to elicit an increase in Fos-lacZ expression. The lack of an immediate effect of raising medium calcium levels on Fos-lacZ expression contrasted with the rapidity of its effect on DNA synthesis, which was significantly inhibited within $6-8 \mathrm{~h}$. In addition, we found that the protein kinase $\mathrm{C}$ inhibitor Ro 31-7549 blocked Fos-lacZ expression induced by TPA but had little or no effect on that elicited by high calcium levels. Thus, although our results indicate that the fos gene product may be involved in mediating epidermal keratinocyte growth arrest in response to differentiative agents such as FBS, TPA and high medium calcium levels, the exact role of this gene product remains unclear.

\section{INTRODUCTION}

The c-fos proto-oncogene is a member of a family of cellular immediate early genes which are expressed in response to a variety of extracellular stimuli (Morgan and Curran, 1989). Fos, the protein gene product of c-fos, binds with Jun, the product of another immediate early gene, c-jun, to form the transcription factor activator protein 1 (AP-1) (Curran and Franza, 1988). This, in turn, recognizes and binds to a specific sequence of nucleotides in DNA to influence the expression of any gene possessing this sequence within its promotor region (Curran and Franza, 1988). Other proteins that may be components of AP-1 include the fos-related antigens (Fras) and other members of the Jun family, encoded by genes such as jun-B and jun-D (Morgan and Curran, 1989)

C-fos was initially identified as the cellular analogue of v-fos, a viral oncogene whose expression can trigger uncontrolled proliferation (Feldman and Yaar, 1991). Thus c-fos has generally been assumed to mediate event(s) necessary for cell growth. There is, however, evidence to indicate that, in some cell types, c-fos may be involved in the regulation of processes contributing to differentiation. For instance, the induction of c-fos and Fos expression have been correlated with both myelomonocytic (Müller et al., 1985) and histiocytic (Hsu et al., 1992) differentiation. Furthermore, Ohta et al. (1991) have found that c-fos expression is induced in differentiating osteoblasts within healing fracture calluses and appears to be involved in the regulation of osteoblastic differentiation. In addition, transfection with c-fos results in the differentiation of F9 teratocarcinoma stem cells (Müller and Wagner, 1984). Thus, expression of c-fos may play a critical role in certain differentiative processes in some tissues.
Recently, Smeyne et al. (1992) have described the generation of a transgenic mouse strain containing the fos-lac $Z$ fusion gene (Schilling et al, 1991). This gene construct possesses all of the known sequences necessary for the regulation of the c-fos gene, including transcriptional initiation, repression, elongation, mRNA termination and turnover, and in addition contains the reporter gene lac $Z$, which encodes the enzyme $\beta$-galactosidase (Schilling et al., 1991; Smeyne et al., 1992). Indeed, the expression of the fusion gene has been shown to correlate with that of the endogenous c-fos gene. Thus, in these transgenic animals, $\beta$ galactosidase serves as a quantitative and relatively facile measure of Fos protein expression. Analysis of $\beta$-galactosidase activity in various tissues has indicated a high level of constitutive expression of the fos-lac $Z$ fusion gene product in bone and in skin (Smeyne et al., 1992). In both cases, the majority of $\beta$-galactosidase activity, i.e. Fos-lacZ expression, was found in cells which were in the process of differentiating. For instance, in bone, expression was observed in mineralizing cartilage cells that were destined to terminally differentiate but not in a proliferative population of cells, such as periosteal cells (Smeyne et al., 1992). In addition, the majority of skin expression of $\beta$-galactosidase activity occurred in the differentiating layers of the epidermis (the stratum granulosum and stratum spinosum). Indeed, Fisher et al. (1991) have also demonstrated large amounts of Fos immunoreactivity in epidermal cells in late stages of differentiation. In the latter study, Fos expression was correlated with keratinization and terminal differentiation rather than proliferation (Fisher et al., 1991). Thus, the induction of c-fos expression may be associated with differentiation of epidermal keratinocytes.

So far, the agents that regulate epidermal keratinocyte proliferation and differentiation in vivo are unclear. But there are

Abbreviations used: AP-1, activator protein 1; dFBS, dialysed FBS; DMSO, dimethyl sulphoxide; FBS, fetal bovine serum; GAPDH, glyceraldehyde3-phosphate dehydrogenase; ITS, insulin-transferrin-selenious acid; MUG, 4-methyl-umbelliferyl $\beta$-D-galactoside; PKC, protein kinase C; SFKM, serum-free keratinocyte medium; TPA, 12-O-tetradecanoyl phorbol 13-acetate; X-Gal, 5-bromo-4-chloro-3-indolyl- $\beta$-galactopyranoside.

* Present address: Medical College of Georgia, Institute for Molecular Medicine and Genetics, 1120 15th Street, Augusta, GA 30912, U.S.A.

$\dagger$ To whom correspondence should be addressed. 
data to indicate a potential role for extracellular calcium in regulating these processes. Thus, a calcium concentration gradient has been measured in fixed skin samples, with low calcium concentrations observed in the proliferative layers and increased calcium levels observed in the more superficial differentiating layers (Menon et al., 1985). In addition, epidermal keratinocytes cultured in vitro proliferate in media containing low calcium concentrations $(<0.1 \mathrm{mM})$ and respond to an elevation in the extracellular calcium levels with inhibited growth and enhanced differentiation (Hennings et al., 1980; Yuspa et al., 1989). Furthermore, evidence indicates that the enzyme protein kinase $\mathrm{C}(\mathrm{PKC})$ may be involved in this response as down-regulation or inhibition of PKC activity prevents the calcium-induced inhibition of proliferation (Bollag et al., 1993) and stimulation of differentiation (Dlugosz et al., 1990). The PKC-activating phorbol esters can also inhibit growth and trigger the expression of differentiation markers (Bollag et al., 1993; Yuspa et al., 1982). It should be noted that keratinocyte differentiation involves the expression of a variety of proteins, as well as a loss of proliferative ability. Although proliferation arrest is not necessarily the stimulus triggering differentiation (Bernerd et al., 1992) and the two may not be precisely linked, it is generally assumed that an inhibition of growth is a relatively early step in the differentiation pathway. Thus, although the physiological regulators of proliferation arrest and differentiation are unknown, investigations have focused on calcium levels and the role of PKC.

In this study, we have used the transgenic mouse strain described above (Smeyne et al., 1992) to investigate the regulation of epidermal keratinocyte Fos expression and proliferation arrest in response to differentiative agents such as elevated medium calcium and phorbol esters in vitro. Primary epidermal keratinocytes possessing the fos-lac $Z$ fusion gene were cultured in a proliferative medium [described by Yada et al. (1989) as modified by Bollag et al. (1993)] and $\beta$-galactosidase activity was measured fluorimetrically as an indication of Fos expression. Our results indicate that several agents that inhibit growth and enhance differentiation in these cells also stimulate Fos expression. Our data also confirm the usefulness of the approach employed here, of culturing cells obtained from mice transgenic for a protooncogene-reporter gene fusion construct, for examining in a quantitative manner the role of gene expression in the regulation of growth and differentiation in vitro.

\section{MATERIALS AND METHODS}

\section{Cell culture}

Transgenic male mice $(\mathrm{B} 6 \mathrm{C} 3 \mathrm{~F} 1 \times \mathrm{B} 6 \mathrm{D} 2)$ possessing the fos-lac $Z$ fusion gene (Smeyne et al., 1992; Schilling et al., 1991) at a copy number of 8-10 (J. I. Morgan, personal communication) were generously provided by Dr. James I. Morgan and Dr. Tom Curran (Roche Research Center, Nutley, NJ, U.S.A.). These transgenic mice were bred to $\mathrm{B} 6 \mathrm{C} 3 \mathrm{~F} 1$ females, and the resulting 1-3-day old neonatal mice were used to prepare transgenic primary epidermal keratinocytes according to the method of Marcelo et al. (1978). Non-transgenic cells were prepared from 2-day old CD1 mice by the same method. Briefly, whole skin was trypsinized $(0.25 \% \mathrm{w} / \mathrm{v}$ trypsin) in Hepes-buffered RPMI 1640 medium, and the epidermis mechanically separated from the dermis. Epidermal cells, released by scraping with forceps, were purified by centrifugation through a stepwise Ficoll gradient $(12-20 \% \mathrm{w} / \mathrm{v})$ and the lower two layers were pooled, washed and counted. Cells were then plated in 6-well dishes (Corning Glass Works, Corning, NY, U.S.A.) in an RPMI medium containing fetal bovine serum (FBS) at a density of 25000 cells $/ \mathrm{cm}^{2}$. After $4 \mathrm{~h}$, the cells were washed with PBS lacking calcium and magnesium (PBS -) and refed with serum-free keratinocyte medium [SFKM: calcium-free modified Eagle's medium containing $25 \mu \mathrm{M}$ calcium, $5 \mathrm{ng} / \mathrm{ml}$ epidermal growth factor, $1 \mathrm{mM}$ glutamine, $90 \mu \mathrm{g} / \mathrm{ml}$ bovine pituitary extract, $5 \mu \mathrm{g} / \mathrm{ml}$ insulin, $5 \mu \mathrm{g} / \mathrm{ml}$ transferrin and $5 \mathrm{ng} / \mathrm{ml}$ selenious acid), $0.05 \%$ (w/v) BSA, 100 units $/ \mathrm{ml}$ penicillin, $100 \mu \mathrm{g} / \mathrm{ml}$ streptomycin and $0.25 \mu \mathrm{g} / \mathrm{ml}$ fungizone] as detailed by Bollag et al. (1993).

It should be noted that no attempt was made to differentiate neonatal mice that inherited the transgene from those that did not. In breeding studies with these mice, an inheritance ratio of $\sim 1: 1$ was obtained, as one would expect if insertion of the transgene does not affect survival to maturity. Therefore, neonatal mice were randomly selected in sufficient quantities such that there was a high probability $(90 \%$ or better) that at least one mouse contributing to the pooled keratinocytes would carry the transgene. Pilot experiments using the fluorimetric $\beta$-galactosidase assay (see below) were then routinely conducted to determine the incubation period necessary to ensure fluorescence intensities within the linear range.

\section{Growth assays}

Cells prepared as described above from neonatal CD1 mice were incubated overnight in SFKM. The medium was then replaced with SFKM containing dialysed FBS (dFBS) at the indicated concentrations. After 4 days of culture in the continuous presence of the agent, the cells were trypsinized and a single-cell suspension was prepared by repeatedly aspirating the cells through an 18 gauge needle. Cell number was then determined using an electronic particle counter (Coulter Electronics, Hialeah, FL, U.S.A).

\section{RNA extraction and Northern analysis}

Transgenic mouse epidermal keratinocytes were grown in SFKM

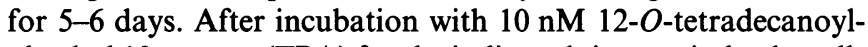
phorbol 13-acetate (TPA) for the indicated time periods, the cells were lysed and total cellular RNA extracted with RNAzolB (Biotecx Laboratories, Houston, TX, U.S.A.) according to the manufacturer's instructions. Three wells of a 6-well plate were pooled, and $50 \mu \mathrm{g}$ of each pooled RNA sample were then electrophoresed on a $1 \%(\mathrm{w} / \mathrm{v})$ agarose/formaldehyde gel and transferred to a Zeta-probe blotting membrane (BioRad, Richmond, CA, U.S.A.). The blots were prehybridized for 5-7 h at $42{ }^{\circ} \mathrm{C}$ with a solution of $50 \% \mathrm{v} / \mathrm{v}$ formamide, $4 \times \mathrm{SSPE}$ $\left(20 \times \mathrm{SSPE}=3 \mathrm{M} \quad \mathrm{NaCl}, \quad 0.2 \mathrm{M} \quad \mathrm{NaH}_{2} \mathrm{PO}_{4}\right.$ and $0.01 \mathrm{M}$ $\mathrm{Na}_{2}$ EDTA, pH 7.4), $5 \times$ Denhardt's reagent, $0.1 \% \mathrm{w} / \mathrm{v}$ SDS and $0.5 \mathrm{mg} / \mathrm{ml}$ salmon sperm DNA. This solution was then replaced with hybridization buffer $(50 \% \mathrm{v} / \mathrm{v}$ formamide, $3 \times \mathrm{SSPE}$, $3 \times$ Denhardt's reagent, $0.1 \% \mathrm{w} / \mathrm{v}$ SDS and $5 \% \mathrm{w} / \mathrm{v}$ dextran sulphate) containing $1 \times 10^{6} \mathrm{cpm} / \mathrm{ml}$ of the appropriate probe. The probes used were a $2.2 \mathrm{~kb} E c o \mathrm{R} 1$ fragment of rat c-fos (Curran et al., 1987), which was generously provided by Dr. Tom Curran (Roche Research Center, Nutley, NJ, U.S.A.) and a $1.2 \mathrm{~kb}$ Pst 1 fragment of glyceraldehyde-3-phosphate dehydrogenase (GAPDH) (a generous gift of Dr. Jill McMahon, Roche Research Center, Nutley, NJ, U.S.A.). Probes were labelled with $\left[\alpha^{-32} \mathrm{P}\right] \mathrm{dCTP}$ using a Prime-a-Gene random primer labelling system (Promega, Madison, WI, U.S.A.).

After hybridization overnight at $42^{\circ} \mathrm{C}$, the membrane probed with c-fos was washed once with $2 \times \mathrm{SSC}(20 \times \mathrm{SSC}=3 \mathrm{M} \mathrm{NaCl}$ and $0.3 \mathrm{M}$ sodium citrate) $/ 0.1 \% \mathrm{SDS}$ at $50^{\circ} \mathrm{C}$ for $15 \mathrm{~min}$ and once with $1 \times \mathrm{SSC} / 0.1 \% \mathrm{SDS}$ at $55^{\circ} \mathrm{C}$ for $15 \mathrm{~min}$; the membrane 
hybridized with GAPDH was washed once with $2 \times$ SSC $/ 0.1 \%$ SDS at room temperature for $15 \mathrm{~min}$, followed by washings with $0.5 \times \mathrm{SSC} / 0.2 \% \mathrm{SDS}$ at room temperature for $15 \mathrm{~min}$ and $0.1 \times \mathrm{SSC} / 0.3 \% \mathrm{SDS}$ at $55^{\circ} \mathrm{C}$ for $20 \mathrm{~min}$. Northern blots were visualized with autoradiography at $-70^{\circ} \mathrm{C}$ using Kodak film and intensifying screens. DNA quantification was performed using a Lynx videodensitometry imaging system (Applied Imaging, Santa Clara, CA, U.S.A.).

\section{Induction of Fos-lacZ expression}

Near-confluent cultures of cells (at a density of 20000-35000 cells $/ \mathrm{cm}^{2}$ ) grown for 3-5 days in SFKM were treated for various times with the appropriate agents at the indicated concentrations. In experiments with the PKC inhibitor Ro 31-7549, the inhibitor was added either simultaneously with or $30 \mathrm{~min}$ before treatment with the appropriate agent, as indicated. Treated and untreated (control) cells were then washed with PBS - and fixed with $3 \%$ (w/v) paraformaldehyde for $15 \mathrm{~min}$ at room temperature. After washing to remove the paraformaldehyde, the cells were solubilized with $0.5 \%(\mathrm{w} / \mathrm{v})$ Triton $\mathrm{X} 100$ for $5 \mathrm{~min}$ at room temperature. $\beta$-Galactosidase activity was then visualized with a histochemical assay using the chromogenic indicator 5-bromo-4-chloro-3indolyl- $\beta$-galactopyranoside (X-Gal) essentially as described by MacGregor et al. (1991). Briefly, after fixation, cells were incubated for approx. 1 day with an X-Gal stain comprising $2 \mathrm{mM} \mathrm{MgCl} 2,5 \mathrm{mM} \mathrm{K}_{3} \mathrm{Fe}(\mathrm{CN})_{6}, 5 \mathrm{mM} \mathrm{K}_{4} \mathrm{Fe}(\mathrm{CN})_{6}, 0.02 \%$ $(\mathrm{w} / \mathrm{v})$ Nonidet P-40, $0.01 \%(\mathrm{w} / \mathrm{v})$ sodium deoxycholate and $1 \mathrm{mg} / \mathrm{ml} \mathrm{X-Gal} \mathrm{in} \mathrm{PBS} \mathrm{-} \beta$-Galactosidase hydrolyses X-Gal to galactose and soluble indoxyl molecules which are oxidized (catalysed by potassium ferrocyanide and ferricyanide) to insoluble indigo (a blue precipitate). Photographs were processed using a red filter to convert the blue of the indigo precipitate to black. Alternatively, $\beta$-galactosidase activity was measured fluorimetrically as described below.

\section{$\boldsymbol{\beta}$-Galactosidase assay}

$\beta$-Galactosidase activity was determined fluorimetrically as described by MacGregor et al. (1991). Briefly, fixed cells were placed in $\mathrm{Z}$ buffer $\left(60 \mathrm{mM} \mathrm{Na}_{2} \mathrm{HPO}_{4}, 40 \mathrm{mM} \mathrm{NaH}_{2} \mathrm{PO}_{4}, 10 \mathrm{mM}\right.$ $\mathrm{KCl}$ and $1 \mathrm{mM} \mathrm{MgSO}_{4}, \mathrm{pH} 7.0$ ) containing $0.1 \%$ w/v Triton $\mathrm{X} 100$. 4-Methylumbelliferyl $\beta$-D-galactoside (MUG; $1.5 \mathrm{mM}$ in $\mathrm{Z}$ buffer plus $0.1 \%$ Triton X100) was added to the cells to initiate the reaction. After the appropriate incubation period (determined by pilot assays), the reaction was terminated with STOP buffer (300 mM glycine plus $15 \mathrm{mM}$ EDTA, pH 11-12), and fluorescence measured with an excitation wavelength of $350 \mathrm{~nm}$ and an emission wavelength of $450 \mathrm{~nm}$ on a Perkin Elmer Model LS 50 fluorimeter (Norwalk, CT, U.S.A.). Samples for autohydrolysis measurement (in the absence of fixed cells) were routinely performed and these 'zero' values subtracted from measured fluorescence. Using purified $\beta$-galactosidase to generate a standard curve, the reaction was found to be linear in the range of fluorescence values between 0 and $\sim 250$.

\section{Measurement of DNA synthesis}

For measurement of $\left[{ }^{3} \mathrm{H}\right]$ thymidine incorporation, near-confluent cultures were incubated in SFKM containing $25 \mu \mathrm{M}$ or $1 \mathrm{mM}$ calcium for the indicated time periods and were then labelled with approx. $1 \mu \mathrm{Ci} / \mathrm{ml}\left[{ }^{3} \mathrm{H}\right]$ thymidine for an additional $1 \mathrm{~h}$. Cultures were washed twice with PBS - and reactions terminated using ice-cold $5 \%$ trichloroacetic acid. Cells were washed with an additional volume of $5 \%$ trichloroacetic acid and with distilled water, and were solubilized in $0.3 \mathrm{M} \mathrm{NaOH}$. An aliquot of this $\mathrm{NaOH}$ extract was counted in a liquid scintillation spectrophotometer.

\section{Statistical analysis}

The significance of differences between mean values was determined using the Student's $t$-test. All experiments were performed at least twice with similar results.

\section{Materials}

TPA (CCR Acquisition Corporation, Edina, MN, U.S.A.) was a generous gift of Dr. Alec Wood (Hoffmann-La Roche, Nutley, NJ, U.S.A.). Dialysed fetal bovine serum (dFBS; dialysed against $0.15 \mathrm{M} \mathrm{NaCl}$ with a $1000 \mathrm{Da}$ molecular mass cutoff), MUG, XGal, BSA (fatty acid-free), trypsin inhibitor, glycine and EDTA were obtained from Sigma (St. Louis, MO, U.S.A.). [methyl${ }^{3} \mathrm{H}$ ]Thymidine (specific radioactivity $40-60 \mathrm{Ci} / \mathrm{mmol}$ ) was purchased from ICN (Irvine, CA, U.S.A.). Fetal bovine serum (FBS) and epidermal growth factor were purchased from Gibco (Gaithersburg, MA, U.S.A.); calcium-free modified Eagle's medium was purchased from Specialty Media (Lafayette, NJ, U.S.A). Bovine pituitary extract was obtained from Upstate Biotechnology (P-Neurext; Lake Placid, New York, U.S.A.). ITS was purchased from Collaborative Research (Bedford, MA, U.S.A.); all other tissue culture reagents were obtained from Hazleton Biologics (Lenexa, KS, U.S.A.). All other materials were of reagent grade.

\section{RESULTS}

Initial studies describing transgenic mice possessing a fos-lac $Z$ fusion gene have demonstrated that the expression of the transgene and endogenous c-fos are well correlated in neurons, neuroblastoma cells and fibroblasts (Schilling et al., 1991; Smeyne et al., 1992, 1993). As shown in Figure 1, the expression of the two genes in primary mouse keratinocytes stimulated with $10 \mathrm{nM}$ TPA exhibited a similar time course. Induction of the $\mathrm{c}$-fos and fusion gene mRNAs was rapid, occurring within $30 \mathrm{~min}$ of exposure to TPA and peaking at $\sim 60 \mathrm{~min}$. Subsequently, mRNA levels rapidly declined, such that after $4 \mathrm{~h}$ of stimulation, c-fos and fusion gene expression approached that of control, untreated cells. After 6 and $24 \mathrm{~h}$ of exposure, mRNA levels of both c-fos and fos-lac $Z$ were essentially undetectable and were not quantified.

Figure 2 illustrates the localization of fusion gene expression. Transgenic cells were incubated with SFKM in the presence and absence of $10 \mathrm{nM}$ TPA, and $\beta$-galactosidase activity was visualized using the chromogenic indicator $\mathrm{X}-\mathrm{Gal}$. Upon reaction with $\beta$-galactosidase, this compound forms a blue precipitate which remains in the vicinity of the enzyme (MacGregor et al., 1991). Photographic processing using a red filter results in the chromophore appearing black, as indicated by the arrows in Figure 2.

Two important points should be noted concerning $\beta$-galactosidase activity in these transgenic cells. First, enzyme activity was localized to the nucleus, as would be expected if expression of the fusion gene correlates with that of the endogenous c-fos gene. Second, expression of $\beta$-galactosidase activity in control, unstimulated cells was quite low. It should be noted that not all cells treated with TPA exhibited the dark staining indicative of X-Gal precipitation, consistent with the fact that the cells comprised a mixture of transgenic and non-transgenic cells (see the Materials and methods section). Rather, areas of stained cells alternated randomly with areas of unstained cells, suggesting clonal expansion of the cells to confluence. 
(a)

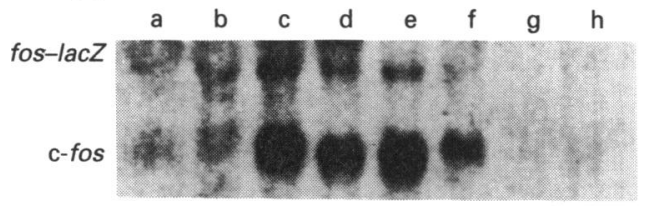

GAPDH

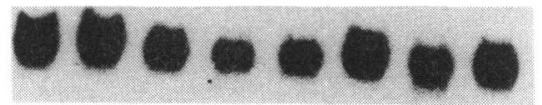

(b)

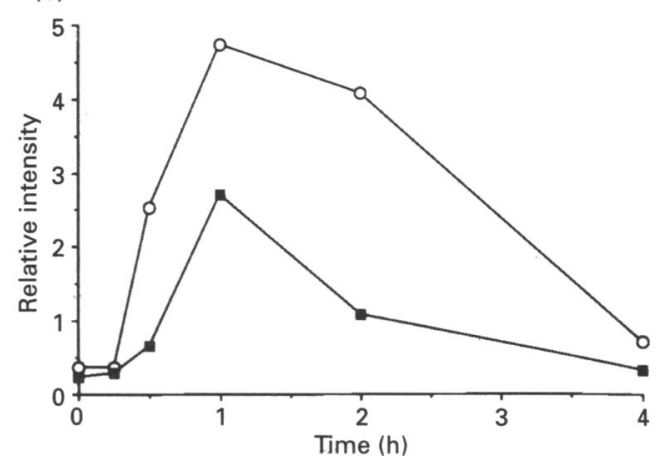

Figure 1 TPA induces c-fos and fos-lacZ mRNA expression

Primary mouse epidermal keratinocytes were prepared trom transgenic neonatal mice and cultured as described in the Materials and methods section. After 5-6 days in SFKM, nearconfluent cultures were switched for the appropriate times to SFKM containing $10 \mathrm{nM}$ TPA. Total cellular RNA was extracted and Northern blotting performed as described in the Materials and methods section. (a) Representative Northern blots probed with sequences specific for $\mathrm{c}$ fos or GAPDH as indicated: lane a, $0 \mathrm{~min} ; b, 15 \mathrm{~min} ; \mathrm{c}, 30 \mathrm{~min} ; \mathrm{d}, 60 \mathrm{~min} ; \mathrm{e}, 2 \mathrm{~h} ; \mathrm{f}, 4 \mathrm{~h}$; g, $6 \mathrm{~h}$; and $\mathrm{h}, 24 \mathrm{~h}$ after TPA exposure. Expression of $\mathrm{c}-$ fos $(\mathrm{O})$ and fos-lacz $(\boldsymbol{\square})$ were quantified relative to that of GAPDH and plotted in (b).

The effect of various agents on Fos-lacZ expression (as measured by $\beta$-galactosidase activity) was then examined in primary mouse epidermal keratinocytes prepared from transgenic mice. These agents included the phorbol ester TPA (10 nM), dFBS $(10 \%, v / v)$ and elevated extracellular calcium levels ( $1 \mathrm{mM}$ versus a control medium calcium concentration of $25 \mu \mathrm{M}$ ). As shown in Figure 3, TPA and dFBS initially stimulated Fos-lacZ expression to a similar extent ( $\sim$ 4-fold over control values) and with a similar time course. A small but significant effect of the two agents was observed as rapidly as $60 \mathrm{~min}$ after treatment, with a peak at $\sim 2 \mathrm{~h}$ of exposure and a maintained enhancement after a $4 \mathrm{~h}$ incubation. After $24 \mathrm{~h}$ of exposure, however, TPA-induced Fos-lacZ expression had returned to control levels, whereas that elicited by dFBS remained significantly elevated over control levels. On the other hand, the pattern of Fos-lacZ expression induced by raising medium calcium concentration was quite distinct (Figure 3). Initially, high calcium had little effect, eliciting essentially no change in Fos-lacZ expression after $30 \mathrm{~min}, 1 \mathrm{~h}, 2 \mathrm{~h}$ and $4 \mathrm{~h}$ of treatment. Indeed, an elevation in Fos-lacZ expression in response to high medium calcium was observed only after $24 \mathrm{~h}$ of treatment.

We next examined Fos-lacZ induction by high extracellular calcium in a more detailed time course (Figure 4). There was a small but significant inhibition of Fos-lacZ expression after relatively short periods of exposure to high calcium (4-6h). More prolonged treatment $(16-48 \mathrm{~h}$ ) resulted in progressively increasing levels of Fos-lacZ expression.
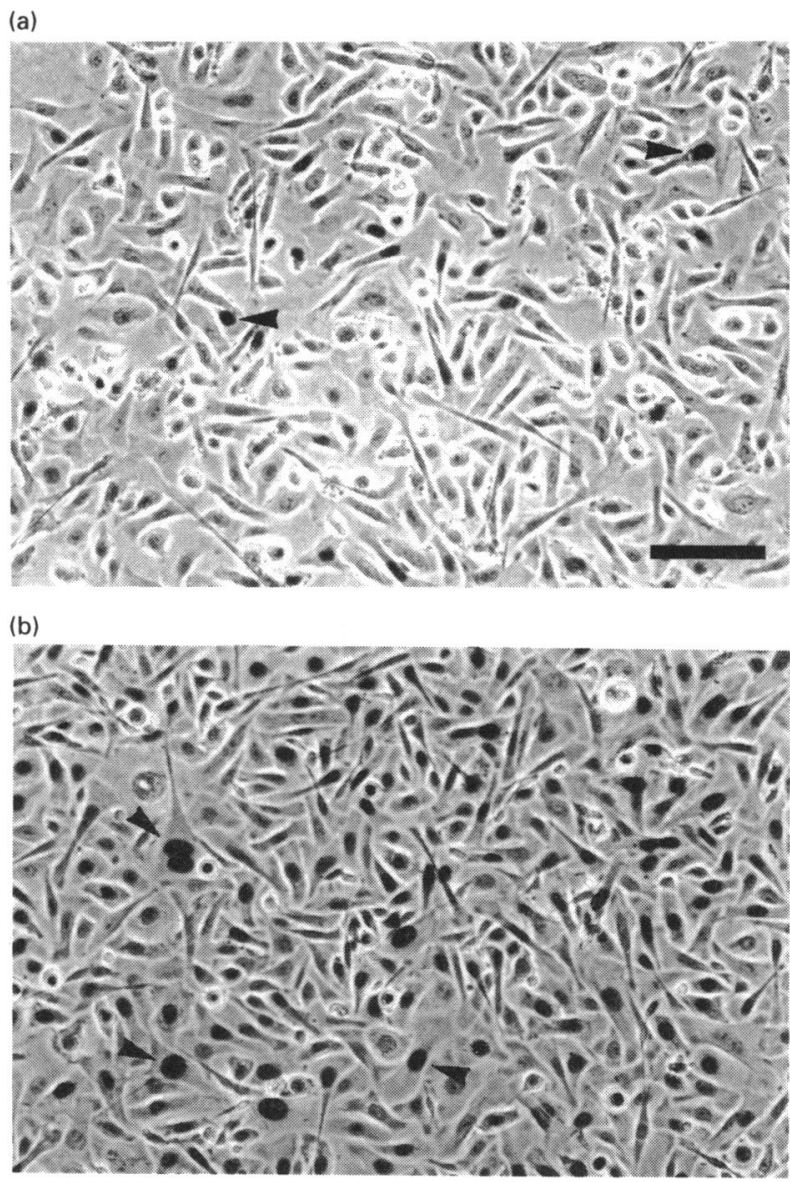

\section{Figure 2 TPA induces nuclear Fos-lacZ fusion protein expression}

Transgenic primary mouse epidermal keratinocytes grown for 4-6 days in SFKM were switched for $2 \mathrm{~h}$ to either (a) control medium or (b) medium containing $10 \mathrm{nM}$ TPA. The cells were fixed and $\beta$-galactosidase activity visualized using the chromogenic indicator X-Gal as described in the Materials and methods section. Photographic processing was performed such that the blue precipitate formed by hydrolysis of $X$-Gal appears black. Closed arrows indicate cell nuclei with high $\beta$-galactosidase activity. Scale bar, $100 \mu \mathrm{m}$.

The effect of raising medium calcium on $\left[{ }^{3} \mathrm{H}\right]$ thymidine incorporation, a measure of DNA synthesis, is shown in Figure 5. Elevating medium calcium significantly inhibited $\left[{ }^{3} \mathrm{H}\right]$ thymidine incorporation after $6-8 \mathrm{~h}$ of treatment. DNA synthesis continued to decline over the next several hours, reaching a plateau after $\sim 16-24 \mathrm{~h}$ exposure. In a second experiment, $\left[{ }^{3} \mathrm{H}\right]$ thymidine incorporation was reduced after $8 \mathrm{~h}$ of treatment with high-calcium medium, and a maximal high-calcium-induced inhibition (to $14 \pm 1 \%$ of the control value) was observed after $24 \mathrm{~h}$. Thus, in epidermal keratinocytes, a temporal dissociation was observed between the inhibition of $\left[{ }^{3} \mathrm{H}\right]$ thymidine incorporation and the stimulation of Fos-lacZ expression induced by increased extracellular calcium levels.

TPA effects are generally presumed to be mediated by the activity of the enzyme PKC, a phospholipid-dependent, calciumsensitive, diacylglycerol-activated protein kinase (Nishizuka, 1989). We have previously shown that the PKC inhibitor Ro 317549 can inhibit TPA-elicited changes in epidermal keratinocyte morphology, $\left[{ }^{3} \mathrm{H}\right]$ thymidine incorporation and cell accumulation (Bollag et al., 1993). We were therefore interested in the effect of this compound on Fos-lacZ expression induced by TPA. Cells pretreated with the indicated concentrations of Ro 31-7549 for 


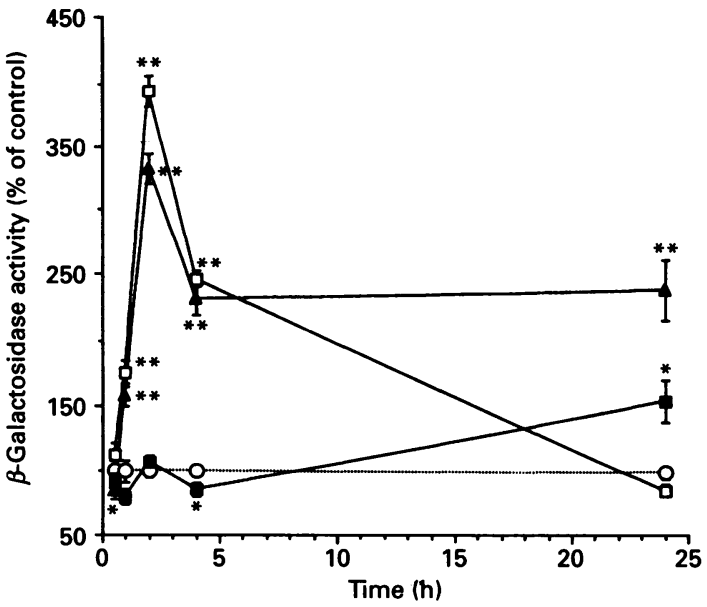

Figure 3 Dialysed FBS, TPA and high-calcium medium induce Fos-lacZ expression

Near-confluent cultures of transgenic primary mouse epidermal keratinocytes, grown for 3-5 days in SFKM, were switched to medium containing no additions (control condition; $O$ ) or containing $10 \% \mathrm{v} / \mathrm{v}$ dFBS (A), $10 \mathrm{nM}$ TPA $(\square)$ or $1 \mathrm{mM}$ calcium ( $\square$ ). After the indicated periods of treatment, cells were fixed and $\beta$-galactosidase activity was measured as detailed in the Materials and methods section. Data points represent values relative to the appropriate control and are the means \pm S.E.M. $(n=3)$ of a representative experiment; ${ }^{*} P \leqslant 0.05$, ${ }^{\star *} P \leqslant 0.005$ versus control.

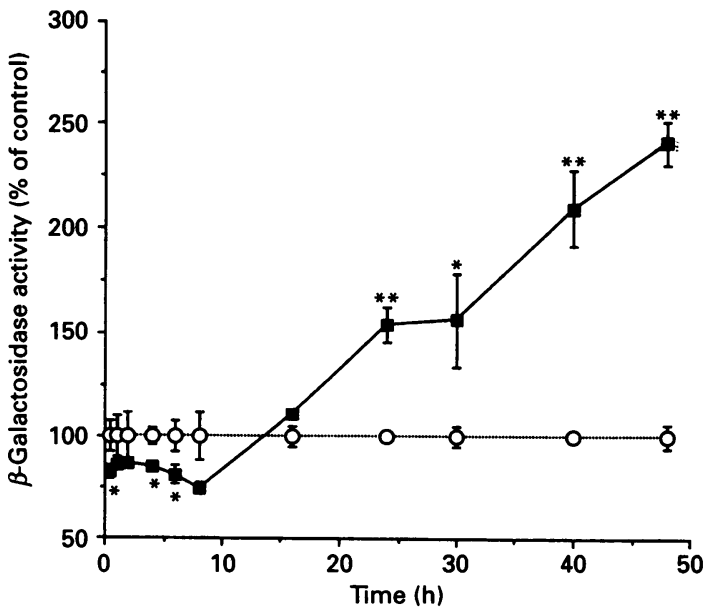

Figure 4 High-calcium medium induces Fos-lacz expression in primary mouse epidermal keratinocytes after $\sim 24 \mathrm{~h}$ of exposure

Near-confluent cultures of transgenic primary mouse epidermal keratinocytes grown for 3-5 days in SFKM were switched for the indicated times to SFKM (control condition of $25 \mu \mathrm{M}$ calcium; O) or SFKM containing high $(1.0 \mathrm{mM}$ ) calcium ( $\square)$. After fixation, $\beta$-galactosidase activity was measured and presented as percentage of the appropriate control values. Data points are the means \pm S.E.M. $(n=3)$ of a representative experiment; ${ }^{*} P \leqslant 0.05$, ${ }^{\star \star} P \leqslant 0.005$ versus control.

$30 \mathrm{~min}$ were exposed to $10 \mathrm{nM}$ TPA for $2 \mathrm{~h}$, after which their $\beta$ galactosidase activity was measured (Figure 6). Again, as in Figure 3, a $2 \mathrm{~h}$ treatment with $10 \mathrm{nM}$ TPA resulted in a significant stimulation of Fos-lacZ expression (approximately 3-fold). Ro 31-7549 blocked in a dose-dependent manner this induction of Fos-lacZ expression in response to TPA, with an $\mathrm{IC}_{50 .}$ of $\sim 0.5 \mu \mathrm{M}$, and almost complete inhibition was observed at a con-

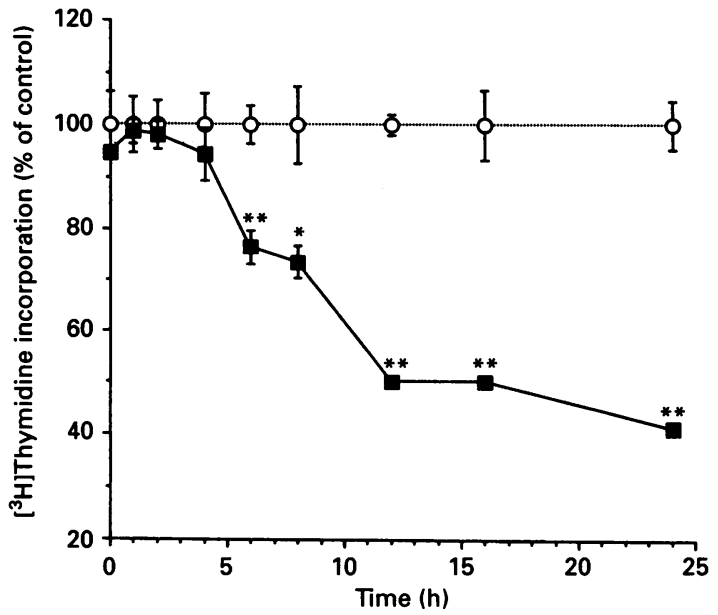

Figure 5 High-calcium medium rapidly inhibits [3 $\left.{ }^{3} \mathrm{H}\right]$ thymidine incorporation into primary mouse epidermal keratinocytes

Near-confluent cultures of primary mouse epidermal keratinocytes from non-transgenic mice grown for 3-5 days in SFKM were switched for the indicated times to SFKM (control condition of $25 \mu \mathrm{M}$ calcium; O) and SFKM containing high $(1.0 \mathrm{mM})$ calcium ( $\square)$. [ $\left.{ }^{3} \mathrm{H}\right]$ Thymidine $(1 \mu \mathrm{Ci} / \mathrm{ml})$ was added for an additional $1 \mathrm{~h}$ labelling period and the cells were processed according to the protocol described in the Materials and methods section. Data points represent the means \pm S.E.M. $(n=3)$ of a representative experiment and are expressed as percentage of the appropriate control; ${ }^{\star} P \leqslant 0.05,{ }^{\star \star} P \leqslant 0.005$ versus control.

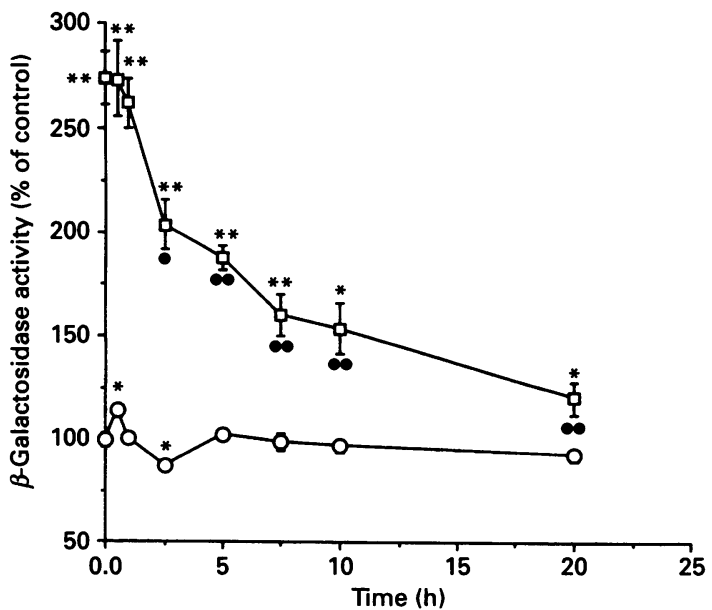

Figure 6 Ro 31-7549 inhibits TPA-induced Fos-lacZ expression in primary mouse epidermal keratinocytes

Transgenic primary mouse epidermal keratinocytes were pretreated for 30 min with SFKM containing the indicated concentrations of Ro $31-7549$ before addition of $10 \mathrm{nM}$ TPA in dimethylsulphoxide (DMSO) ( $\square$ ) or DMSO (control condition; O). All samples contained a final concentration of $0.1 \%(\mathrm{v} / \mathrm{v})$ DMSO. After a further 2 hour incubation, cells were fixed and $\beta$-galactosidase activity was measured. Results are expressed as percentage of the control (in the absence of Ro $31-7549$ or TPA) and represent the means \pm S.E.M. $(n=3)$ of a representative experiment; ${ }^{\star} P \leqslant 0.05,{ }^{\star \star} P \leqslant 0.005$ versus control and $\cdot P \leqslant 0.001$, $\because P \leqslant 0.005$ versus TPA.

centration of $2 \mu \mathrm{M}$. Thus, Fos-lacZ expression elicited by TPA appears to be mediated by PKC.

Previous studies have also suggested a possible role for PKC in the regulation of epidermal keratinocyte growth and differentiation by elevated extracellular calcium levels (Wirth et al., 1987; Dlugosz et at., 1990; Bollag et al., 1993). Figure-7 illustrates 


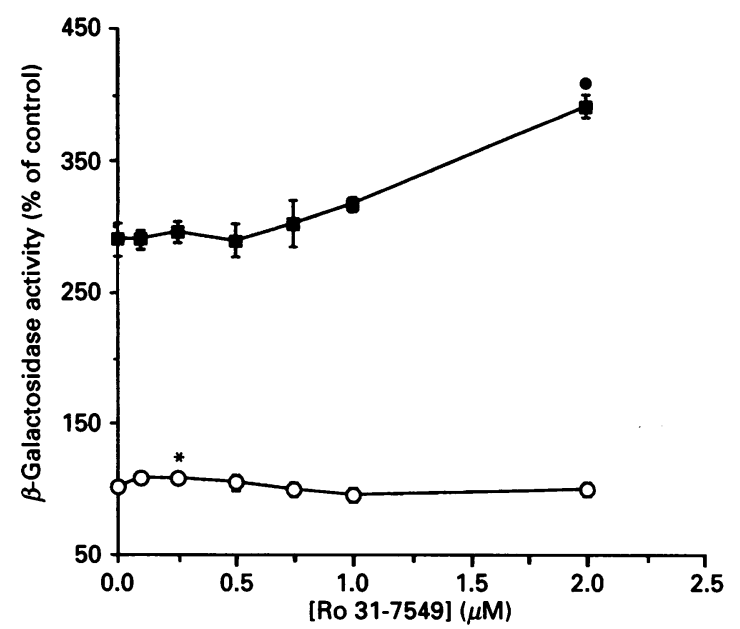

Figure 7 Ro 31-7549 has little or no effect on high-calcium-induced Fos-lacz expression in primary mouse epidermal keratinocytes

Transgenic primary mouse epidermal keratinocytes were treated for $48 \mathrm{~h}$ with SFKM containing the indicated concentrations of Ro 31-7549 in the presence of high $(1 \mathrm{mM}$; $\square$ ) and low $(25 \mu \mathrm{M} ; O)$ calcium. Cells were then fixed and $\beta$-galactosidase activity was measured. Results are expressed as percentage of the control value (in the absence of Ro 31-7549 or high calcium) and represent the means \pm S.E.M. $(n=3)$ of a representative experiment. All values in the presence of high calcium are significantly different from the control $(25 \mu \mathrm{M})$ value $(P \leqslant 0.0005)$; also ${ }^{*} P \leqslant 0.025$ versus control and $\cdot P \leqslant 0.005$ versus high calcium.

the effect of Ro 31-7549 on high-calcium-induced Fos-lacZ expression. Cells were treated with high-calcium $(1 \mathrm{mM})$ medium and the indicated concentrations of Ro 31-7549 for $48 \mathrm{~h}$, and $\beta$ galactosidase activity was then measured. At low concentrations, Ro 31-7549 had little or no effect on high-calcium-elicited Fos-lacZ expression, whereas at higher doses Ro 31-7549 exposure produced a small enhancement of Fos-lacZ expression (Figure 7). Experiments in which cells were treated for $24 \mathrm{~h}$ (rather than $48 \mathrm{~h}$ ) with Ro 31-7549 in the presence of highcalcium medium yielded similar results: little or no effect at low doses and a small elevation of Fos-lacZ expression at higher concentrations (results not shown). These results suggest, therefore, that Fos induction in response to raising extracellular calcium is not mediated by the activity of PKC.

Both acute TPA exposure and elevated medium calcium levels (Hennings et al., 1980; Yuspa et al., 1982, 1989) (Figure 3) are known to inhibit keratinocyte proliferation and, as shown in Figures 3 and 4, both treatments also increase Fos-lacZ expression. As dFBS also elicits Fos-lacZ expression (Figure 1), we investigated the effect of dFBS on cell growth. As shown in Figure 8, dFBS inhibited in a dose-dependent fashion proliferation of epidermal keratinocytes, with a maximal inhibition observed at $10-20 \%(\mathrm{v} / \mathrm{v}) \mathrm{dFBS}$ and an $\mathrm{IC}_{50}$ of $\sim 2.5 \%$. Low concentrations of dFBS $(<1.25 \%)$ had little or no effect on cell number. This finding was perhaps unexpected as FBS typically induces proliferation of most cell types, although FBS (both whole and chelexed) was previously reported to decrease the colony-forming efficiency of a mouse keratinocyte cell line (Kaighn et al., 1988). Thus, all three agents tested both induced Fos-lacZ expression and inhibited the growth of primary mouse epidermal keratinocytes.

\section{DISCUSSION}

Our results indicate that the expression of the endogenous c-fos gene correlated well with that of the fos-lac $Z$ fusion gene in primary epidermal keratinocytes, in that the time courses of the induction of expression of the two genes by TPA were parallel (Figure 1). Moreover, the induction of c-fos and fos-lac $Z$ gene expression (Figure 1) and of $\beta$-galactosidase activity (Figure 3 ) were also parallel, suggesting the validity of using measurements of the activity of this enzyme as a marker for Fos expression. The more rapid changes observed with Northern blotting (Figure 1) versus $\beta$-galactosidase activity (Figure 3 ) are consistent with the fact that mRNA production precedes protein synthesis. In addition, we have shown that the fusion gene product, like the native protein, is localized to the nucleus (Figure 2), providing further evidence of the correlation between $\beta$-galactosidase activity and Fos expression. The expression of both genes is quite low in control, untreated cultures of these proliferating epidermal keratinocytes (Figures 1 and 2), and the Northern blotting technique lacks the sensitivity necessary for routine quantification of $f o s$ induction in such a cell system. Thus, the use of the transgenic keratinocytes and measurement of $\beta$-galactosidase activity allows a sensitive and quantitative determination of the induction of Fos protein expression. Nevertheless, the Fos-lacZ fusion protein may have a slightly longer half-life than the endogenous Fos protein (Schilling et al., 1991; Smeyne et al., 1992); however, the rapidity with which TPA-elicited $\beta$-galactosidase activity decreased from its peak at $2 \mathrm{~h}$, and the parallel time courses of induction of $\beta$-galactosidase activity and c-fos mRNA expression, suggest that this slight difference in kinetics does not significantly affect the results or our interpretation of them.

Our data demonstrate that several agents that inhibit keratinocyte proliferation also stimulate Fos expression. Fos, a component of the transcription factor AP-1, serves to couple rapid signal-transduction events, such as activation of $\mathrm{PKC}$, to altered expression of selected genes, and upstream regulatory regions of the c-fos gene are known to contain DNA sequences that encode response elements for serum and phorbol esters (Schilling et al., 1991). Thus, our finding that both TPA and dFBS treatment resulted in a rapid, transient rise in Fos-lacZ expression in primary keratinocytes isolated from transgenic mice (Figure 3) suggests that physiological stimulus-transcription coupling is retained by this in vitro reporter system.

We have previously shown that the PKC inhibitor Ro 31-7549 prevents many of the effects of the PKC activator TPA (Bollag et al., 1993). Thus, the finding that Ro 31-7549 blocks TPAinduced fos-lac $Z$ expression (Figure 6) suggests that TPA mediates its effects on Fos-lacZ expression via activation of PKC, and that Ro 31-7549 can inhibit that activity in keratinocytes. It should be noted that the $\mathrm{IC}_{50}$ of $\sim 0.5 \mu \mathrm{M}$ obtained for Ro 31-7549-induced inhibition of TPA-elicited Fos-lacZ expression is consistent with the effective range necessary to reverse other TPA responses (Bollag et al., 1993), in particular phorbol ester-induced growth arrest. The ability of Ro 31-7549 to block both Fos expression and growth arrest elicited by TPA suggests a role for Fos in the inhibition of proliferation. As noted earlier, there is also evidence in the literature to indicate that fos expression may be correlated with differentiation in certain tissue types, including the epidermis. Thus, both Smeyne et al. (1992) and Fisher et al. (1991) found that Fos expression was greatest in the differentiating layers of the skin, with little expression observed in the proliferative basal layer. The results of BassetSeguin et al. (1991) also suggest a role for Fos in differentiation of keratinocytes: these authors have demonstrated that in psoriasis, a disease characterized by hyperproliferation and abnormal differentiation, the expression of fos mRNA is decreased. This finding is however contrary to the observations of others who found either no change (Elder et al., 1990) or an 


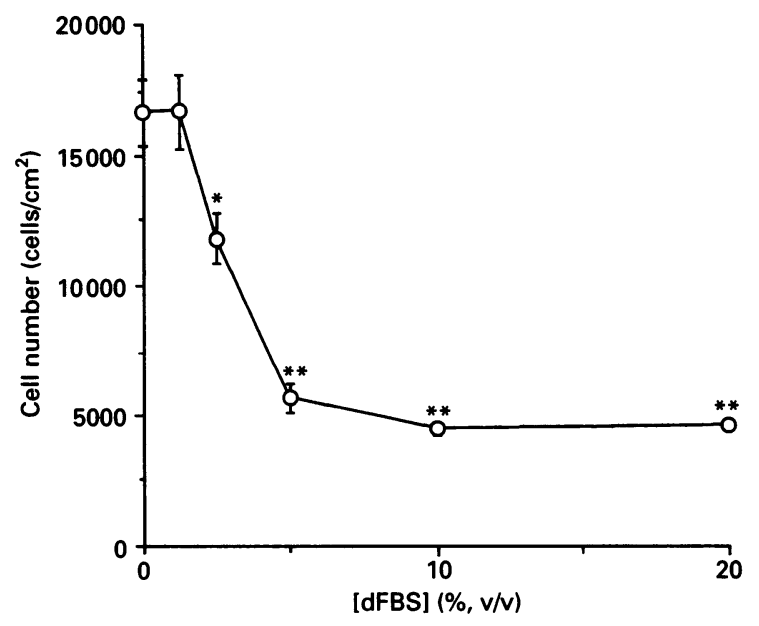

Figure 8 Dialysed FBS inhibits the proliferation of primary mouse epidermal keratinocytes

Cells from non-transgenic mice cultured overnight in SFKM were switched to medium containing various concentrations $(\mathrm{v} / \mathrm{v})$ of $\mathrm{dFBS}$. Cell number was determined after 4 days of treatment and represented a 2.6 -fold increase from day $0(P \leqslant 0.0005$ versus control cell number on day 4). Data points are the means \pm S.E.M. (control: $n=6$; FBS: $n=3$ ) of a representative experiment; ${ }^{\star} P \leqslant 0.025,{ }^{\star \star} P \leqslant 0.005$ versus control.

increase (Mordovtsev et al., 1988) in fos mRNA expression in psoriatic lesions. Our data suggest that enhanced fos expression is associated with inhibition of keratinocyte proliferation. Thus, agents such as dFBS, TPA and elevated medium calcium levels which induce Fos-lacZ expression also inhibit growth (Hennings et al., 1980; Bollag et al., 1993) (Figure 8) and elicit differentiation (Hennings et al., 1980; Yuspa et al., 1989; Dlugosz et al., 1990) of epidermal keratinocytes.

It should be noted, nevertheless, that there is a dissociation between the induction of Fos-lacZ expression and the inhibition of DNA synthesis elicited by raising medium calcium levels. Thus, $\left[{ }^{3} \mathrm{H}\right]$ thymidine incorporation was significantly decreased within $6-8 \mathrm{~h}$ after elevation of extracellular calcium concentrations (Figure 5), whereas Fos-lacZ expression at this time was slightly below control levels (Figure 4). Our observation of a decrease in Fos-lacZ expression in response to increasing medium calcium levels is consistent with a previous study in which raising the medium calcium level was shown to rapidly inhibit epidermal growth factor-induced fos expression in a Balb/MK keratinocyte cell line (Di Fiore et al., 1988). But the lack of a rapid effect of elevating extracellular calcium concentration on the induction of Fos-lacZ expression is somewhat unexpected. The fos-lacZ transgene is known to possess a calcium/cyclic AMP response element (Schilling et al., 1991) which, when activated by elevated cyclic AMP or intracellular calcium levels, should result in an induction of $\beta$-galactosidase expression. In epidermal keratinocytes, raising the medium calcium concentration has been demonstrated to elicit phosphoinositide turnover, Ins $(1,4,5) P_{3}$ production and increases in cytosolic calcium concentration within minutes (Jaken and Yuspa, 1988; Tang et al., 1988; Hennings et al., 1989; Kruszewski et al., 1991; Lee and Yuspa, 1991). Thus, our findings that raising the medium calcium levels resulted in Fos-lacZ expression only after many hours (Figures 3 and 4) is quite perplexing. The mechanism underlying this dissociation between changes in intracellular calcium concentration and Fos expression is unknown and requires further investigation. Thus, although it is clear that calcium and fos are involved in some aspect of the regulation of proliferation and differentiation, their respective roles appear to be quite complex.

Further evidence that the effects of elevated medium calcium levels are not straightforward is provided by the interactions of Ro 31-7549 and calcium. We have shown previously that Ro 317549 can block the inhibitory effect of high calcium medium on epidermal keratinocyte growth (Bollag et al., 1993). Thus, if Fos were to play a role in the high-calcium-induced inhibition of proliferation, Ro 31-7549 might be expected to affect Fos-lacZ expression as well. But at concentrations at which Ro 31-7549 blocks the antiproliferative effect of elevating extracellular calcium $(0.5-1 \mu \mathrm{M})$, this agent has little or no effect on highcalcium-elicited Fos-lacZ expression (Figure 7). Although this result suggests that the high-calcium-induced Fos expression is not mediated by PKC, it is nevertheless perhaps somewhat surprising as there is evidence to indicate a role for PKC in calcium-induced proliferation arrest and differentiation (Wirth et al., 1987; Dlugosz et al., 1990; Bollag et al., 1993) and in the induction of Fos expression by PKC-activating phorbol esters (Figures 3 and 6).

The dissociation between raising medium calcium levels or activating PKC with TPA and the induction of Fos expression may be the result of differences in the stage of differentiation elicited by the two agents. Thus, whereas TPA elicits the rapid progression to a late differentiative state typical of the granular layer of skin, calcium induces a more slowly developing differentiation process with the attendant expression of spinous cell markers (Dlugosz and Yuspa, 1993). It is possible that fos expression is correlated with the late stage of epidermal differentiation. This hypothesis is supported by the pattern of Fos expression observed in skin in vivo (Fisher et al., 1991; Smeyne et al., 1992) and would explain the length of time $(\sim 24 \mathrm{~h})$ necessary for induction of Fos-lacZ expression in keratinocytes in response to raising extracellular calcium concentration (Figures 3 and 4). In this scenario, inhibition of proliferation might well precede the expression of the transgene, as seen in Figures 4 and 5, and might in fact be independent of fos induction. Ro 31-7549 could then prevent the high-calciumelicited growth inhibition without affecting the later differentiative step of fos expression. Further studies are necessary to probe this hypothesis.

In summary, the studies reported here show that primary epidermal keratinocytes isolated from transgenic mice bearing a fos-lac $Z$ fusion gene provide a relatively facile, quantitative system for investigating the role of Fos expression in the regulation of keratinocyte growth and differentiation. Although our results suggest that c-fos may mediate rapid transcriptional changes associated with keratinocyte growth inhibition following PKC activation or serum exposure, its precise role in the growthinhibitory response to elevated calcium medium remains unclear.

We thank Dr. J. Morgan and Dr. T. Curran for providing us with the transgenic mice and for their helpful suggestions. We would like to express our appreciation to Dr. B. Hillbush for his assistance with Northern analysis. The assistance of Ms. Diane Bonagura in the preparation of this manuscript is also gratefully acknowledged.

\section{REFERENCES}

Basset-Seguin, N., Escot, C., Moles, J. R., Blanchard, J. M., Kerai, C. and Guilhou, J. J. (1991) J. Invest. Dermatol. 97, 672-678

Bernerd, F., Magnaldo, T. and Darmon, M. (1992) J. Invest. Dermatol. 98, 902-910

Bollag, W. B., Ducote, J. and Harmon, C. S. (1993) J. Invest. Dermatol. 100, 240-246 Curran, T. and Franza, B. R., Jr. (1988) Cell 55, 395-397

Curran, T., Gordon, M. B., Rubino, K. C. and Sambucetti, L. C. (1987) Oncogene 2, 79-84

Di Fiore, P. P., Falco, J., Borrello, I., Weissman, B. and Aaronson, S. A. (1988) Mol. Cell. Biol. 8, 557-563

Dlugosz, A. A. and Yuspa, S. H. (1993) J. Cell Biol. 120, 217-225 
Dlugosz, A. A., Pettit, G. R. and Yuspa,. S. H. (1990) J. Invest. Dermatol. 94, 519a Elder, J. T., Tavakkot, A., Klein, S. B., Zeigler, M. E., Wicha, M. and Voorhees, J. J. (1990) J. Invest. Dermatol. 94, 19-25

Feldman, S. R. and Yaar, M. (1991) Arch. Dermatol. 127, 707-711

Fisher, C., Byers, M. R., ladarola, M. J. and Powers, E. A. (1991) Development 111, 253-258

Hennings, H., Michael, D., Cheng, C., Steinert, P., Holbrook, K. and Yuspa, S. H. (1980) Cell 19, 245-254

Hennings, H., Kruszewski, F. H., Yuspa, S. H. and Tucker, R. W. (1989) Carcinogenesis 10 $777-780$

Hsu, S.-M., Xie, S.-S., El-Okda, M. O. and Hsu, P.-L. (1992) Am. J. Pathol. 140, 155-165 Jaken, S. and Yuspa, S. H. (1988) Carcinogenesis 9, 1033-1038

Kaighn, M. E., Camalier, R. F., Bertolero, F. and Saffioti, U. (1988) In Vitro 24, 845-854

Kruszewski, F. H., Hennings, H., Yuspa, S. H. \& Tucker, R. W. (1991) Am. J. Physiol. 261 C767-C773

Lee, E. and Yuspa, S. H. (1991) Carcinogenesis 12, 1651-1658

MacGregor, G. R., Nolan, G. P., Fiering, S., Roederer, M. and Herzenberg, L. A. (1991) in Methods in Molecular Biology (Murray, E. J., ed.), pp. 217-235, Humana Press, Clifton

Marcelo, C. L., Kim, Y. G., Kaine, J. L., and Voorhees, J. J. (1978) J. Cell Biol. 79, 356-370

Menon, G. K., Grayson, S. and Elias, P. M. (1985) J. Invest. Dermatol. 84, 508-512
Mordovtsev, V. N., Starkov, I. V., Zabarovsky, E. R. and Kisselev, L. L. (1988) Arch. Dermatol. Res. 280, 8-11

Morgan, J. I. and Curran, T. (1989) Trends Neurochem. Sci. 12, 459-462

Müller, R. and Wagner, E. F. (1984) Nature (London) 311, 438-442

Müller, R., Curran, T., Müller, D. and Guilbert, L. (1985) Nature (London) 314, 546-548 Nishizuka, Y. (1989) Cancer 63, 1892-1903

Ohta, S., Yamamuro, T., Lee, K., Okumura, H., Kasai, R., Hiraki, Y., Ikeda, T., Iwasaki, R., Kikuchi, H., Konishi, J. and Shigeno, C. (1991) FEBS Lett. 284, 42-45

Schilling, K., Luk, D., Morgan, J. I. and Curran, T. (1991) Proc. Natl. Acad. Sci. U.S.A. 88, 5665-5669

Smeyne, R. J., Schilling, K., Robertson, L., Luk, D., Oberdick, J., Curran, T. and Morgan, J. I. (1992) Neuron 8, 13-23

Smeyne, R. J., Vendrell, M., Hayward, M., Bakers, S. J., Miao, G. G., Schilling, K., Robertson, L. M., Curran, T. and Morgan, J. I. (1993) Nature (London) 363, 166-169 Tang, W., Ziboh, V. A., Isseroff, R. and Martinez, D. (1988) J. Invest. Dermatol. 90, 37-43 Wirth, P. J., Yuspa, S. H., Thorgiersson, S. S. and Hennings, H. (1987) Cancer Res. 47, 2831-2838

Yada, Y., Ozeki, T., Meguro, S., Mori, S. and Nozawa, Y. (1989) Biochem. Biophys. Res. Commun. 163, 1517-1522

Yuspa, S. H., Ben, T., Hennings, H. and Lichti, U. (1982) Cancer Res. 42, 2344-2349

Yuspa, S. H., Kilkenny, A. E., Steinert, P. M. and Roop, D. R. (1989) J. Cell Biol. 109, 1207-1217

Received 30 December 1993; accepted 18 January 1994 